\title{
POTENSI PRODUKSI HIJAUAN DAN KOMPOSISI KIMIA RUMPUT SUDAN (Sorghum sudanense) SEBAGAI SUMBER HIJAUAN PAKAN LOKAL DI WILAYAH PAPUA
}

\author{
Onesimus Yoku \\ Fakultas Peternakan Universitas Papua \\ Email: yokuones@yahoo.co.id; onesyoku@gmail.com
}

\begin{abstract}
ABSTRAK
Paper ini bertujuan untuk memberikan gambaran tentang potensi produksi hijauan, komposisi kimia nutrein dan antinutrisi, dan potensi pengembangan rumput sudan (Sorghum sudanense) di kawasan timur Indonesia dan khususnya wilayah Papua sebagai hijauan pakan lokal ternak ruminansia. Hijauan pakan lokal ini sangat potensial dikembangkan di wilayah papua, karena cocok pada lahan kering, tahan kekeringan, berkemampuan tumbuh kembali dan sangat responsif terhadap pemupukan dan pengairan, serta tumbuh dan berkembang secara alamiah mulai dataran rendah hinggi dataran tinggi diseluruh wilayah Papua. Perlakuan pemupukan nitrogen, phosfor, dan kalium berpengaruh signifikann terhadap produksi bahan kering, bahan organik dan aplikasi pupuk anjuran sesuai hasil penelitian adalah $300 \mathrm{~kg} \mathrm{~N} / \mathrm{ha} ; 300 \mathrm{~kg} \mathrm{P/}$ ha; dan $150 \mathrm{~kg} \mathrm{P} / \mathrm{ha}$.
\end{abstract}

Kata kunci: rumput sudan, pemupukan, produksi hijauan, nutrien dan antinutrisi

\begin{abstract}
This paper aims to provide an overview of the potential forage production, nutrients and antinutrients chemical composition, and the potential development of Sudan grass (Sorghum sudanense) in eastern part of Indonesia, particularly in the Papua island as a local forage ruminant. Local forage is very potential to be developed in Papua island, because it adapts to dry land and drought resistant, capable of growing back, and is very responsive to fertilizer and irrigation, as well as can be growth either in lowland and highland. Nitrogen, phosphorus and potassium fertilizer treatments have significant effect to dry matter and organic matter productions of Sudan grass with their level dosage recommendations are $300 \mathrm{~kg} \mathrm{~N} / \mathrm{ha}, 300 \mathrm{~kg} \mathrm{P} /$ ha, and $150 \mathrm{~kg} \mathrm{P} / \mathrm{ha}$, respectively.
\end{abstract}

Keywords: sudan grass, fertilizer, forage production, nutrient and antinutrition

\section{PENDAHULUAN}

Rumput sudan (Sorghum sudanense) dinilai berpotensi untuk dikembangkan terutama pada musim kering sebagai pakan alternative dan-atau dikembangkan untuk lahan-lahan kering, terutama di kawasan Timur Indonesia (Utomo, 2003). Sebagai rumput potong, rumput sudan mempunyai kemampuan tumbuh kembali (sehabis dipotong) yang lebih baik dibanding dengan rumput yang berumur pendek lainnya dan sangat responsif terhadap pemupukan dan pengairan.

Penelitian rumput sudan telah lama ditinggalkan karena adanya jenis-jenis rumput baru yang mempunyai keunggulan dalam produksi biomassa dan umur potongnya. Namun demikian jenis-jenis rumput unggul tersebut sebagian besar membutuhkan lahan yang relatif subur dengan manajemen pengelolaan yang intensif, maka penelitian terhadap rumput sudan sebagai jenis rumput yang tahan hidup di lahan kering perlu dilanjutkan.

Kajian-kajian tentang potensi produksi dan nilai nutrisi rumput sudan sebagai jenis hijauan pakan lokal masih sangat jarang terutama di wilayah papua, sementara hampir di seluruh wilayah Papua dapat ditemukan rumput sudan mulai dataran rendah hingga pegunungan. Paper ini bertujuan untuk memberikan gambaran tentang potensi produksi hijauan, komposisi kimia nutrein dan antinutrisi rumput sudan, serta potensi pengembangan rumput sudan di kawasan timur Indonesia dan khususnya wilayah Papua sebagai hijauan pakan lokal ternak ruminansia. 


\section{DASAR PEMIKIRAN}

Pada saat pertumbuhan vegetatif, tanaman banyak membutuhkan unsur N. Salah satu cara untuk menjaga agar produksi hijauan tetap terjaga adalah dengan pemupukan. Unsur nitrogen $(\mathrm{N})$, fosfor $(\mathrm{P})$ dan kalium (K) merupakan unsur hara makro yang sangat diperlukan oleh tanaman, bila ketiga unsur hara ini terdapat dalam keseimbangan yang tidak sesuai maka pertumbuhan tanaman akan terganggu atau tumbuh merana. Aplikasi pupuk anjuran untuk tanaman sorghum, masing-masing dasar aplikasi pupuk nitrogen $200 \mathrm{lb}$ per acre atau setara dengan $225 \mathrm{~kg} \mathrm{~N}$ per ha (Sumner et al., 1965), dan teknologi anjuran untuk budidaya sorghum dengan rasio pupuk P dan K adalah 2:1 (Roesmarkam dan Soebandi, 1995).

Menurut Bogdan (1977) bahwa masih terdapat variasi jarak tanam dalam baris yaitu $15^{-100} \mathrm{~cm}$, namun demikian jarak tanam yang paling sesuai adalah 25-40 cm. Populasi tanaman sorghum per ha adalah 100.000 tanaman atau berkisar antara 100.000-250.000 tanaman per ha (Roefaida, 1992; dan Anonymous, 1990). Semakin besar unsur hara nitrogen yang tersedia maka pertumbuhan vegetatif tanaman semakin dapat dipacu. Pemberian pupuk efektif meningkatkan produksi rumput sudan, namun demikian tingginya pupuk nitrogen berakibat tingginya kandungan nitrat $\left(\mathrm{NO}_{3}\right)$ dan asam sianida (hydrocyanic acid atau HCN) pada hijauan.

\section{HASIL PENELITIAN RUMPUT SUDAN}

Penelitian produksi hijauan rumput sudan pada musim kemarau telah dilaksanakan di Kebun Pendidikan Penelitian dan Pengembangan Pertanian (KP4) UGM di Kalitirto-Berbah, Yogyakarta. Analisis komposisi kimia nutrien atau analisis proksimat sampel hijauan (AOAC, 2005), serta analisis zat/ senyawa antinutrisi yaitu kandungan asam sianida dan nitrat menurut petunjuk Sudarmadji et al. (1984) dilakukan di laboratorium Hijauan Makanan Ternak dan Pastura, Fapet UGM dan laboratorium teknologi pertanian, Fateta UGM.

Pupuk yang digunakan berupa pupuk NPK (urea, $46 \% \mathrm{~N}$; SP36, 36\% $\mathrm{P}_{2} \mathrm{O}_{5}$; dan $\mathrm{KCl}, 60 \% \mathrm{~K} 2 \mathrm{O}$ ) dilaksanakan dengan 3 (tiga) level dosis pupuk NPK yang berbeda pada level pupuk N (o, 150, 300, dan $450 \mathrm{~kg} \mathrm{~N} / \mathrm{ha}$ ), pupuk $\mathrm{P}$ dan $\mathrm{K}$ pada level yang sama yaitu $300 \mathrm{~kg} \mathrm{P} / \mathrm{ha}$ dan $150 \mathrm{~kg} \mathrm{~K} / \mathrm{ha}$ dengan kode $\mathrm{Po}, \mathrm{P}_{1}, \mathrm{P}_{2}$, dan $\mathrm{P}_{3}$, dengan jarak tanam $40 \times 20 \mathrm{~cm}$.

\section{Serapan Unsur NPK dan Produksi Hijauan Rumput Sudan}

Rata-rata serapan unsur N, P, dan K tertinggi masing-masing pada perlakuan $\mathrm{P}_{3}$ dan terendah pada perlakuan Po. Hasil analisis statistik serapan unsur NPK jaringan rumput sudan menunjukkan bahwa perlakuan dosis pupuk NPK berpengaruh signifikan dan uji DMRT untuk bahwa perlakuan pupuk NPK berbeda nyata antar perlakuan Po (o,0248 ton/ha), P1 (o,1423 ton/ha), P2 (o,2622 ton/ha), dan $\mathrm{P}_{3}(0,3578$ ton/ha) untuk variabel serapan N. Secara umum serapan tertinggi pada unsur $\mathrm{N}$ kemudian unsur $\mathrm{K}$ dan P. Serapan $\mathrm{N}$ tinggi karena pupuk $\mathrm{N}$ diberikan pada beberapa level, sedangkan pupuk $\mathrm{P}$ dan $\mathrm{K}$ diberikan pada level yang sama untuk setiap level pupuk N. Hubungan serapan unsur NPK dan produksi BK dan BO disajikan dengan

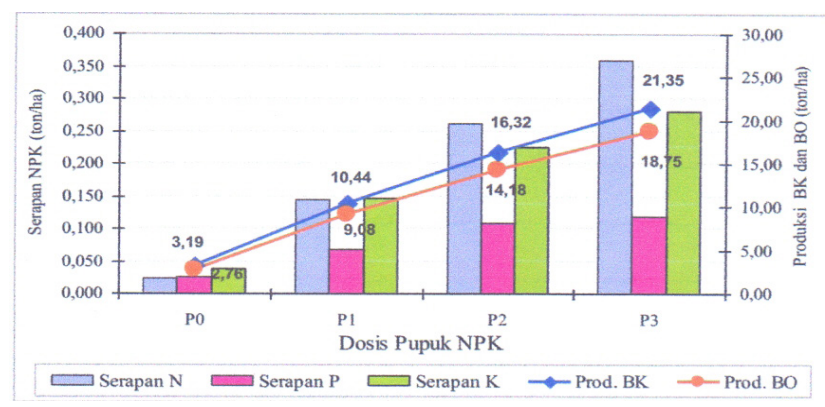

Gambar 1. Grafik serapan NPK dengan produksi BK dan BO.

Berdasarkan Gambar 1 diatas nampak bahwa serapan $\mathrm{N}$ berperanan menentukan serapan $\mathrm{P}$ dan $\mathrm{K}$ serta produksi BK dan BO. Hasil analisis statistik produksi BK dan BO rumput sudan menunjukkan bahwa perlakuan dosis pupuk NPK berpengaruh nyata dan hasil uji DMRT produksi BK dan BO rumput sudan per ha dalam sekali potong menunjukkan bahwa masing-masing produksi BK dan BO pada perlakuan Po (3,19 ton/ha; 2,76 ton/ha) berbeda nyata dengan perlakuan P1 (10,44 ton/ha; 9,08 ton/ ha), P2 (16,32 ton/ha; 14,18 ton/ha), dan P3 (21,35 ton/ha; 18,75 ton/ha). Perlakuan P1 berbeda nyata dengan perlakuan $\mathrm{P}_{2}$ dan $\mathrm{P}_{3}$, tetapi antara perlakuan $\mathrm{P}_{2}$ dan $\mathrm{P}_{3}$ tidak berbeda nyata.

Berdasarkan persentase peningkatan produksi BK dibandingkan dengan perlakuan Po (tanpa pupuk), maka berturut-turut terjadi kenaikan produksi untuk P1, P2 dan P3 sebesar 69,44\%, 80,45\% dan $85,06 \%$, dan persentase peningkatan untuk produksi BO adalah sebesar $69,60 \%, 80,54 \%$, dan $85,28 \%$. Persentase peningkatan produksi ini menunjukan adanya penurunan persentase peningkatan pada perlakuan $\mathrm{P}_{3}$. Dengan demikian pupuk nitrogen pada perlakuan $\mathrm{P} 2$ (300 kg N, $300 \mathrm{~kg} \mathrm{P}$ dan $150 \mathrm{~kg} \mathrm{~K} /$ ha) merupakan level optimal untuk produksi bahan kering dan produksi bahan organik rumput sudan. 


\section{Komposisi Kimia Nutrien dan Antinutrisi Rum- put Sudan}

Analisis statistik komposisi PK, SK, BETN akibat perlakuan pupuk NPK pada musim kemarau berpengaruh signifikan tetapi komposisi HCN berpengaruh tidak signifikan. Hasil DMRT kandungan protein kasar rumput sudan menunjukkan bahwa perlakuan Po $(7,71 \%)$ berbeda nyata dengan P1 (12,29\%), P2 (13,46\%), dan $\mathrm{P}_{3}$ (13,60\%). Perlakuan $\mathrm{P} 1$ berbeda nyata dengan $\mathrm{P}_{2}$ dan $\mathrm{P}_{3}$, sedangkan antara perlakuan P2 dan P3 tidak berbeda nyata. Dengan demikian dapat dikatakan bahwa perlakuan pupuk NPK meningkatkan kandungan protein kasar rumput sudan walaupun perlakuan $\mathrm{P}_{2}$ dan $\mathrm{P}_{3}$ berpengaruh sama terhadap kandungan PK. Uji DMRT serat kasar dan BETN rumput sudan menunjukkan perlakuan Po berbeda nyata dengan $\mathrm{P}_{1}, \mathrm{P}_{2}$, dan $\mathrm{P}_{3}$, dimana perlakuan pemupukan NPK meningkatkan SK, tetapi sebaliknya menurunkan BETN.

Komposisi HCN rumput sudan tidak signifikan dipengaruhi oleh perlakuan pupuk NPK. HCN tertinggi terdapat pada perlakuan P2 (295,50 ppm), disusul P1 (210,03 ppm), P3 (162,75 ppm) dan terendah pada perlakuan Po (115,63 ppm). Hasil DMRT kandungan nitrat rumput sudan menunjukkan bahwa perlakuan Po $(5575,57 \mathrm{ppm})$ berbeda nyata dengan P1 (1704,36 ppm), P2 (1463,13 ppm) dan P3 (1729,18 ppm), sedangkan antara perlakuan P1, P2, dan $\mathrm{P}_{3}$ tidak berbeda nyata. Walaupun komposisi antinutrisi $\mathrm{HCN}$ dan nitrat pada level tidak toksik, masing-masing $\mathrm{HCN}$ lebih rendah dari $750 \mathrm{ppm}$ dan nitrat lebih rendah dari $6000 \mathrm{ppm}$, tetapi terdapat indikasi bahwa perlakuan pupuk NPK meningkatkan HCN dan sebaliknya menurunkan nitrat rumput sudan. Komposisi kedua antinutrisi ini tidak pada level toksik menunjukkan bahwa rumput sudan tidak mengalami stres, karena Selk, et al. (1995) yang mengemukakan bahwa aplikasi pupuk $\mathrm{N}$ akan meningkatkan konsentrasi nitrat rumput sudan hybrida, cuaca panas menyebabkan tanaman stresss akibatnya terjadi akumulasi nitrat.

\section{POTENSI PENGEMBANGAN RUMPUT SUDAN DI WILAYAH PAPUA}

Rumput sudan (Sorghum sudanense) dinilai berpotensi untuk dikembangkan di kawasan Timur Indonesia, dan secara khusus Papua. Produksi rumput sudan dapat dioptimalkan dengan pengelolaan yang baik melalui pengaturan jarak tanam dan pemberian pupuk NPK (nitrogen, fosfor dan kalium).

Rumput sudan membutuhkan pupuk nitrogen dalam jumlah besar yang harus diberikan setiap kali pemangkasan, disamping itu pupuk $\mathrm{P}$ diberikan tergantung kandungannya di dalam tanah. Pemberian pupuk efektif meningkatkan produksi rumput sudan, namun demikian tingginya pupuk nitrogen berakibat tingginya kandungan nitrat $\left(\mathrm{NO}_{3}\right)$ dan asam sianida (hydrocyanic acid atau HCN) pada hijauan.

Kandungan HCN rumput sudan dapat ditekan sekitar 50-75\% bila dikeringkan (hay) karena asam sianida bersifat mudah menguap, sedangkan penanggulangan bahaya nitrat adalah dengan pemberian pakan suplemen. Penambahan pakan suplemen sebagai sumber energi bagi mikrobia rumen, agar mampu mengubah nitrat menjadi nitrit, dan nitrit menjadi amonia dengan adanya enzim nitrat reduktase dan nitrit reduktase yang dihasilkan mikrobia rumen.

Berdasarkan laporan hasil penelitian rumput sudan, maka jarak tanam yang dapat menjadi acuan adalah antara $20-40 \mathrm{~cm}$ dengan level pupuk NPK masing-masing $300 \mathrm{~kg} \mathrm{~N} / \mathrm{ha}, 300 \mathrm{~kg} \mathrm{P} / \mathrm{ha}$, dan 150 $\mathrm{kg} \mathrm{K} / \mathrm{ha}$. Khusus pemupukan $\mathrm{N}$ dapat ditingkatkan hingga $450 \mathrm{~kg} \mathrm{~N} / \mathrm{ha}$.

\section{KESIMPULAN}

Rumput sudan dinilai berpotensi untuk dikembangkan di wilayah Papua sebagai salah satu hijauan pakan lokal dengan pengelolaan yang optimal melalui pemberian pupuk. Perlakuan level pupuk NPK disarankan menjadi acuan patokan, masing-masing $300 \mathrm{~kg} \mathrm{~N} / \mathrm{ha}, 300 \mathrm{~kg} \mathrm{P} / \mathrm{ha}$, dan $150 \mathrm{~kg} \mathrm{~K} / \mathrm{ha}$.

\section{DAFTAR PUSTAKA}

Anonymous. 1990. Teknologi budidaya sorgum. Balai Informasi Pertanian Propinsi Irian Jaya. Jayapura.

AOAC. 2005. Official Methods of Analysis of the Association of Official Analytical Chemists. Published by the Association of Official Analytical Chemists, Maryland, USA.

Bogdan, A.V. 1977. Tropical Pasture and Fodder Plants (Grasses and Legumes). First Published. Longman Inc., New York.

Karniati, R. Soedradjad dan B.P. Utomo. 1995. Pengaruh formulasi, frekuensi pemberian dan takaran pemupukan terhadap pertumbuhan dan hasil Sorgum. Risalah Simposium : Prospek Tanaman Sorgum Untuk Pengembangan AgroIndustri. Edisi Khusus Balitkabi No. 4 :153-160. Novizan. 2002. Petunjuk Pemupukan yang Efektif. Cetakan Pertama. Agro Media Pustaka. Jakarta.

Owen, F.G and W.J. Moline. 1970. Sorghum for Forage. In Sorghum Production and Utilization. Major Feed and Food Crops in Agriculture and Food Series (Editors : Wall, J.S. and W.M. Ross). The Avi Publishing Company, Inc. Westport 
Cennecticut.

Roefaida, E. 1992. Pengaruh Kadar Lengas Tanah pada Berbagai Fase Pertumbuhan Tanaman Terhadap Hasil Sorghum (Sorghum vulgare L.). Tesis. Program Studi Agronomi, Jurusan IlmuIlmu Pertanian, program Pascasarjan UGM. Yogyakarta.

Rosmarkam, A dan N.W. Yuwono. 2002. Ilmu Kesuburan Tanah. Cetakan Pertama. Penerbit Kanisius. Yogyakarta.

Roesmarkam, S dan Subandi. 1995. Prospek pengembangan sorgum sebagai penunjang swasembada pangan dan pakan. Risalah Simposium : Prospek Tanaman Sorgum Untuk Pengembangan Agro-Industri. Edisi Khusus Balitkabi No. 4 : 104-109.
Sudarmadji, S., B. Haryono dan Suhardi. 1984. Prosedur Analisa untuk Bahan Makanan dan Pertanian. Edisi Ketiga. Cetakan Pertama. Penerbit Liberty, Yogyakarta.

Selk, G.E., G. L. Strickland, D. R. Wagner, dan S. Janloo. 1995. The relationship among nitrate content and nutritional value in hybrid sudangrass hay. Agronomy Research Stations, Oklahoma State University.

Utomo, R. 2003. Penyediaan Pakan di Daerah Tropik: Problematika, Kontinuitas, dan Kualitas. Pidato Pengukuhan Jabatan Guru Besar pada Fakultas Peternakan Univeritas Gadjah Mada. Yogyakarta. 